\title{
Playing God in Frankenstein's Footsteps: Synthetic Biology and the Meaning of Life
}

\author{
Henk van den Belt
}

Received: 5 November 2009 / Accepted: 5 November 2009/Published online: 29 November 2009

(C) The Author(s) 2009. This article is published with open access at Springerlink.com

\begin{abstract}
The emergent new science of synthetic biology is challenging entrenched distinctions between, amongst others, life and non-life, the natural and the artificial, the evolved and the designed, and even the material and the informational. Whenever such culturally sanctioned boundaries are breached, researchers are inevitably accused of playing God or treading in Frankenstein's footsteps. Bioethicists, theologians and editors of scientific journals feel obliged to provide an authoritative answer to the ambiguous question of the 'meaning' of life, both as a scientific definition and as an explication with wider existential connotations. This article analyses the arguments mooted in the emerging societal debates on synthetic biology and the way its practitioners respond to criticism, mostly by assuming a defiant posture or professing humility. It explores the relationship between the 'playing God' theme and the Frankenstein motif and examines the doctrinal status of the 'playing God' argument. One particularly interesting finding is that liberal theologians generally deny the religious character of the 'playing God' argument - $\mathrm{a}$ response which fits in with the curious fact that this argument is used mainly by secular
\end{abstract}

H. van den Belt $(\triangle)$

Applied Philosophy Group, Wageningen University, Hollandseweg 1,

$6706 \mathrm{KN}$ Wageningen, The Netherlands

e-mail: henk.vandenbelt@wur.nl organizations. Synthetic biology, it is therefore maintained, does not offend so much the God of the Bible as a deified Nature. While syntheses of artificial life forms cause some vague uneasiness that life may lose its special meaning, most concerns turn out to be narrowly anthropocentric. As long as synthetic biology creates only new microbial life and does not directly affect human life, it will in all likelihood be considered acceptable.

Keywords Anthropocentrism · Frankenstein . Hubris $\cdot$ Meaning of life $\cdot$ Playing God

\section{Life on the Drawing Board}

Synthetic biology is "the code name for engineering using the machinery of the cell, from tinkering with existing organisms all the way to the design of life from scratch' ([41]: 11). In the wake of the transition of biology from a taxonomy-based to an informationbased discipline, '[synthetic] biologists dream of controlling the machinery of life like engineers control device layouts on a computer chip' (ibid.: 10).

Among those intent upon giving life a complete makeover, the well-known researcher J. Craig Venter appears unrivalled in his capacity to attract venture capital. He and his team are working on a long-term project involving the transplantation of 'minimal' genomes (i.e. genomes stripped of all dispensable 
genes) made from synthesized DNA into host cells whose genomes have been removed. The artificial creatures thus obtained will then be used as a 'chassis' upon which all kinds of economically useful genes can be mounted. 'We're moving from reading the genetic code to writing it', Venter himself explains [50]. On 31 May 2007 he caused a stir when the US Patent and Trademark Office published the patent application his institute had filed on the creation and various useful applications of a new life form called Mycoplasma laboratoriums (J. [33]). The claims are very broadly formulated; specific mention is made of the creation of new synthetic organisms for the production of biofuels like hydrogen and ethanol. At present, such applications may sound futuristic, but Venter, it seems, wants to send a message to the general public that his enterprises (not only the non-profit $\mathrm{J}$. Craig Venter Institute but also the company Synthetic Genomics, Inc.; all patent rights will be assigned to the latter) intend to play a key role in solving the urgent problems of energy supply and climate change.

Though the spotlight of publicity seems to be trained on Venter, he is not the only person who is active in the emerging field of synthetic biology. A growing clique of young enthusiasts is clustering around such luminaries as Tom Knight, Drew Endy, Jay Keasling and George Church, who specialize in designing and constructing artificial biological systems, ideally 'from scratch', and who thereby take a more bottom-up approach to synthetic biology [21, 44]. In their view, the implementation of this task calls for standardization [26]. Leading synthetic biology researchers from MIT, Harvard and California are busily engaged in building a 'library' (or 'catalogue') of interchangeable standard parts called 'BioBricks', or pieces of DNA with known functions, from which practitioners can draw at will to construct new life forms. By putting together carefully selected building blocks it is possible to design genetic circuits capable of regulating successive reaction steps in metabolic pathways for the production of valuable substances within the cell. The insertion of such circuits in a microbial host organism can turn the latter into a tiny biochemical factory.

\section{Controlling Life: Continuities and Cultural Impacts}

The rise of synthetic biology can be seen as a continuation, and interim culmination, of some longer-term trends that are characteristic of major strands in the development of western science and technology.

Historians of science have pointed out that in embracing the engineering ideal of 'controlling life' contemporary synthetic biologists may be regarded as heirs to the visionary American biologist Jacques Loeb, who was pursuing a similar ambition as early as 1900 [5, 12, 40, 45]. Loeb advocated a 'technology of living substance', which would enable man to act as a creator of new life forms.

For some, the ambition to control is inextricably linked with the 'reconceptualization of biological life [...] as informational', in parallel with a similar conviction in nanotechnology that 'the physical world can be manipulated as if it were information' ([36]: 104). Synthetic biology can indeed be seen as the culmination of a long-standing and still ongoing trend of progressive 'informatization' of the biological world. The informational view of life that has dominated molecular biology since Watson and Crick unravelled the structure of DNA in 1953 is increasingly being materialized in tangible technological applications, even to the point of blurring the distinction between living matter and information [59].

The historical roots of synthetic biology can be traced even farther back. Several practitioners justify their new field by quoting the famous statement by physicist Richard Feynman: 'What I cannot create I do not understand' ([44]: 61). ${ }^{1}$ Feynman's dictum echoes similar statements by eighteenth-century luminaries such as Giambattisto Vico ('verum et factum convertuntur' or the true and the made are convertible) and Immanuel Kant ('reason has insight only into what it itself produces according to its own plan'; see [35]: 19). The idea that there is a very close connection between knowing and making, between understanding an object and the ability to create or (re-)assemble it, is not at all foreign to the tradition of western science and philosophy. An interesting illustration of what one could dub the Vico-KantFeynman Principle is provided by nineteenth-century synthetic organic chemistry ([7]: 168). In several

\footnotetext{
${ }^{1}$ See also the following statement by two synthetic biologists: 'Until we can assemble a form of life in vitro from defined, functionally understood macromolecules and small molecule substrates, how can we say that we understand the secret of life?' ([28]: 5).
} 
respects, synthetic chemistry is indeed a historical precursor to present-day synthetic biology. No wonder then that some contemporary practitioners attempt to draw heuristic lessons from this example [6, 63]. Synthetic biology may also have inherited some of the cultural ambivalences and reservations pertaining to the 'natural-versus-artificial' dichotomy from synthetic chemistry [59].

Synthetic biology adopts the epistemological approach of synthetic chemistry, but pursues it with the resources of modern information technology. In informational terms, Feynman's dictum boils down to Von Neumann's motto 'If you can't compute it you don't understand it!'. 2 New life forms can be designed by writing 'programs' in the quaternary 'code' of the four DNA nucleotides. Hence, the work of synthetic biologists also resembles that of software designers.

The 'informatization' of the biological world may have a disenchanting effect on our view of life. Life itself is increasingly understood in terms of 'information processing' or 'computation' and cells and organisms are seen as computers that can be easily (re)programmed according to our wishes. Rather than evolving naturally, living beings become the product of deliberate design. Many are worried that life will lose its special meaning when such reductionist views prevail. A case in point is the way living organisms are considered in patent law. The European Directive on the Legal Protection of Biotechnological Inventions (Directive 98/44/EC) gives the following definition of the key object of protection: '... "biological material" means any material containing genetic information and capable of reproducing itself or being reproduced in a biological system' (art. 2.1 sub a). Notice that not just genes and cells but complete organisms can be brought under this definition. During political debates on the implementation of the Directive in the Netherlands in 20032004, several members of parliament expressed concern that the new legislation would reduce living beings to the status of biological material. In response to this concern, cabinet ministers pointed out that "all living beings consist of biological material, but of course are more than just biological material" ([25], 23 $\mathrm{ff})$. This facile defence is rather disingenuous, however, as organisms clearly meet the definition of 'biological material' given in the Directive and on that count must

\footnotetext{
$\overline{2}$ Von Neumann's motto has inspired the scientific work of molecular biologist Sydney Brenner ([9]: 141).
}

be held to be such material (besides, the Directive declares entire organisms to be patentable). There is no escape from the conclusion that in modern patent law plants and animals are being reduced to the status of raw material or carrier of genetic information.

Synthetic biology puts heavy pressure on many of the culturally entrenched distinctions and demarcations that are constitutive of our symbolic order. It shifts or blurs the boundaries between matter and information, life and non-life, nature and artefact, organic and inorganic, Creator and creature, the evolved and the designed. In science and technology studies, entities that challenge the settled boundaries of nature and society are often designated as 'monsters' [34]. Like the creations of synthetic biology, Victor Frankenstein's creature was a prime example of a 'monster' in this particular sense. ${ }^{3}$ Whenever culturally sanctioned boundaries are breached by such 'monsters', researchers are quickly accused of playing God or of treading in Frankenstein's footsteps. Indeed, in recent times these types of accusations have triggered societal debates on the moral and symbolic implications of synthetic biology in which the question about the 'meaning' of life has also found a prominent place. By following the tropes of 'playing God' and emulating Frankenstein in their discursive settings, I therefore also hope to gain a useful contextual angle from which to deal with the latter question.

\section{Playing God and Following Frankenstein}

Responding to the news that Craig Venter and his team had filed for a patent on Mycoplasma laboratorium, the leader of the ETC Group, Pat Mooney, declared in June 2007:

'For the first time, God has competition. Venter and his colleagues have breached a societal

\footnotetext{
3 "Shelley's "monster" is something new in world literature, a being which disturbs the very categories by which we make logical sense of the world: reality and fantasy, being and nonbeing, life and death, natural and constructed, organic and artificial, animate and inanimate. Victor will continue to produce a series of nominations for his creature (including "fiend", "abortion", "daemon", "spectre", "vampire", "devil", "vile insect", "detested form" and so on) because, as Shelley well knew, there are no authentic names for a being who questions the very logical categories created by human language' ([2]: 52).
} 
boundary, and the public hasn't even had a chance to debate the far-reaching social, ethical and environmental implications of synthetic life.' [27].

This statement seems particularly apt with regard to synthetic biology. However, it is definitely not the first time that an assertion of this or a similar kind has been made. It sounds rather hackneyed to say that man is playing God. The recombinant-DNA debate in the 1970s already gave rise even then to a book entitled Playing God [29]. In recent decades this accusation has been levelled innumerable times at classical biotechnologists (e.g. [48]). Similarly, genetic engineering in its classical form has been charged with breaching critical boundaries. For members of the ETC Group, apparently, such considerations fail to constitute a persuasive reason to abstain from hammering the same message home time and again, as is shown by the frequency with which the expression 'playing God' continues to appear in their publications and press releases (see for instance [52]). This is not at all surprising. Journalists also tend to resort to this metaphor when reporting new developments in the life sciences. When, for example, back in 1999 Business Week discussed Venter's newly initiated research on the minimal genome, it chose the title 'Playing God in the Lab' [13]. And in May 2007 Newsweek printed a lead story on synthetic biology, with a portrait of a thoughtful, upward-looking Craig Venter adorning the cover alongside the boldly printed words 'Playing God'. This expression has meanwhile become, as publicist and science journalist Philip Ball remarks, a lazy journalistic cliché and an alarmist slogan [4]. However, it is a cliché that may still enable writers or NGOs to attract the attention of a large audience.

In discussions on biotechnology and synthetic biology, alongside and in combination with allusions to the presumed arrogance of playing God, a name is very often invoked that many scientists consider a tainted 'F-word': Frankenstein. In fact, the Frankenstein theme is closely entwined with the motif of playing God. As Mary Shelley herself wrote in 1831 in the introduction to her gothic novel Frankenstein; or, The Modern Prometheus: 'Frightful must it be; for supremely frightful would be the effect of any human endeavour to mock the stupendous mechanism of the Creator of the world.' ([53]: 9). The main character of the novel, Victor Frankenstein, ultimately brought disaster upon himself and his loved ones by indulging in the 'unhallowed arts' of 'bestowing animation upon lifeless matter' (ibid.: 53). He aspired 'to become greater than his nature [would] allow' (ibid: : 54). In other words, Frankenstein wanted to play God and was as severely punished for his transgression as Prometheus, who had stolen fire from the gods. As a Dutch literary critic succinctly explains: 'The moral seems clear, and is more relevant than ever in the $21 \mathrm{st}$ century, which is dominated by the advancing genetic and bio-technologies: do not play God and beware of the dangers of technology' [55]. In his book Frankenstein's Footsteps, Jon Turney calls the story of Frankenstein 'the governing myth of modern biology' ([58]: 3). Mary Shelley herself took pains to point out that the theme of her gothic novel was not entirely the product of her own imagination. In fact, the subject matter resonated with scientific ideas that had circulated around 1800, such as Erasmus Darwin's views on the 'spontaneous generation' of $\operatorname{life}^{4}$ and Luigi Galvani's ideas of using electricity to animate lifeless matter:

'Perhaps a corpse would be re-animated; galvanism had given token of such things: perhaps the component parts of a creature

\footnotetext{
${ }^{4}$ In the 1831 introduction to her novel, Mary Shelley referred to the conversations in the summer of 1816 between Lord Byron and Percy Shelley about Erasmus Darwin's experiments: 'They talked of the experiments of Dr Darwin, (I speak not of what the Doctor really did, or said that he did, but, as more to my purpose, of what was then spoken of as having been done by him), who preserved some piece of vermicelli in a glass case, till by some extraordinary means it began to move with voluntary motion.' ([53], 9). The story of a piece of 'vermicelli' that suddenly became alive sounds quite incredible, but the term may mean 'little worms' as well as refer to a species of Italian pasta. In an editorial note to Erasmus Darwin's philosophical poem Temple of Nature, Martin Priestman unravels the tangle of confusions ([16] [1803]; Editor's Note 1.247). In an Additional Note to his poem, entitled 'Spontaneous Vitality of Microscopic Animals', Erasmus Darwin had reported on the research done by previous scholars on the subject of spontaneous generation: 'By the experiments of Buffon, Reaumur, Ellis, Ingenhouz, and others, microscopic animals are produced in three or four days, according to the warmth of the season, in the infusions of all vegetable or animal matter. One or more of these gentlemen put some boiling veal broth into a phial previously heated in the fire, and sealing it up hermetically or with melted wax, observed it to be replete with animalcules in three or four days.' ([16] [1803], Canto 1, Additional Note 1).
} 
might be manufactured, brought together, and endued with vital warmth.' ([53]: 8). ${ }^{5}$

This brief summary cannot possibly do justice to the many subtleties and layers of meaning that lie hidden in Mary Shelley's novel. In the popular imagination, based more on retellings and especially on Hollywood movies than on the original novel, the Frankenstein story has been reduced to the straightforward, one-dimensional tale of a mad scientist who created a hideous and rampaging monster. The original story has been turned into the 'Frankenstein myth' [58] and much of the ambiguity of the novel has been lost. One of the effects of this process is that Victor Frankenstein's noble intentions, including his wish 'to banish disease from the human frame and render man invulnerable to any but a violent death' ([53]: 42) have been eclipsed. Some interpreters have drawn attention to other neglected aspects of the novel. Langdon Winner and Stephen Jay Gould argue that Frankenstein's greatest moral failure was that he refused to take proper responsibility and care for the creature he himself had put into this world ([62]: 306314; [30]). Ellen ter Gast, finally, identifies Frankenstein's secretiveness and his refusal to communicate with his scientific colleagues and the wider public as a further shortcoming ([56]: 116, 132).

Frankenstein is a recurrent reference point in modern debates on biotechnology and synthetic biology. Bioethicist Bernard Rollin, for example, referred to the Frankenstein story when discussing the ethical and social aspects of animal biotechnology [51]. At the height of the British food scare around genetically modified foods in 1998, the Prince of Wales single-handedly poured oil on troubled waters by launching the term 'Frankenfoods'. Mary Shelley's creature is yet again unearthed in connection with synthetic biology. Hope Shand and her co-authors refer to Craig Venter under the heading 'Dr Frankenstein, I presume' [52]. Incidentally, in 1999, when discussing his plans to construct an artificial bacterium with a minimal genome, Venter himself declared with some bravado: 'Shelley would have loved this!' ([18]: 110). However, forewarned by the furore caused by Dolly the cloned sheep, he was smart enough to first solicit ethical advice from a

\footnotetext{
${ }^{5}$ For more information on 'galvanistic' experiments performed in Mary Shelley's time, see [39]: 11-17.
}

panel of leading bioethicists and theologians which he himself installed, the so-called Ethics of Genomics Group led by Arthur Caplan and Mildred Cho. In the event, the panel saw no fundamental objections against Venter's plans to construct a minimal genome and eventually delivered the desired positive advice $[15,64]$. Ironically, journalist Chris Mooney commented that Victor Frankenstein could have saved himself a lot of trouble, had he conducted his affairs in the same smart way as Venter:

'If only Victor Frankenstein had had some media savvy, he might have been J. Craig Venter. Rather than living in dread of his appalling creature, he could have assembled a panel of bioethicists and theologians to bless it, applied for a Swiss government grant to research it, and hired an investment bank to explore an initial public offering-FrankenCell Inc.- to exploit the results of his research' [42].

Venter is indeed a pre-eminent example of the modern 'bio-entrepreneur', who deftly combines scientific and commercial objectives [57]. To Victor Frankenstein, however, 'wealth was an inferior object' ([53]: 42).

Although the name of Mary Shelley's tragic hero is invoked in connection with classical biotechnology as well as with synthetic biology, Philip Ball takes the view that the comparison with Frankenstein's unhallowed arts seems much more appropriate for the latter field:

'Compared with conventional biotechnology and genetic engineering, the risks involved in synthetic biology are far scarier. Whether you approve of them or not, GMOs are more like patients with an organ transplant than Frankenstein's monster. There is no sense in which genetic engineers are 'making life'-but that is what synthetic biologists propose to do, if indeed they have not already done so' [3].

Ball later went back on this statement, as we will see below.

Between Humility and Defiance

To avoid unwelcome associations with Dr Frankenstein's pursuits and to escape the charge of playing God, many 
current practitioners of synthetic biology plead humility and deny that their activities resemble anything that might come close to 'creating' or 'making' life. Thus MIT Professor George Church elaborates on the purportedly humble comparison of synthetic biologists with simple engineers, even if he does not seem entirely willing to give up the coveted epithet of 'intelligent designers':

'We're acting as engineers, possibly as intelligent designers. The religiously-inclined would not put humans in the same league with the "Intelligent Designer", or God. As creative as we become, and as industrious and as good as we are at designing and manufacturing living things, which we've been doing since the stone age - no matter how good we get at that, it's like calling a candle a supernova. A candle is not a supernova; it's not even in the same league. And we, as intelligent designers, are not in the same league as the "Intelligent Design" forces that started the whole shebang. We're not designing sub-atomic particles from scratch; we're not designing galaxies. We're really not even designing the basic idea of life; we're just manipulating it.' ([10]; my italics).

To which one might reply that in this sense Victor Frankenstein was not designing life (let alone the idea of life) 'from scratch' either: 'The dissecting room and the slaughterhouse furnished many of my materials (...)' ([53]: 55). If the construction of artificial life forms only deserves to be called creation of life when it is created literally out of nothing (creatio ex nihilo), then we can be pretty sure that this elusive aim will never be achieved. But wasn't Adam formed from the dust of the earth?

Belatedly, Venter also takes a more modest stance. While he used to compare himself with Frankenstein, he now insists that he is not in the business of creating life, but is merely engaged in 'modifying life to come up with new life forms' [8]. Perhaps with the cover page of Newsweek in mind, he now dismisses any suggestion that he is trying to play God as 'media sensationalism' (ibid.). His collaborator Hamilton Smith once gave a less timid and less evasive reply to the charge that he was playing God: 'We don't play'. Equally defiant is the response of James Watson, the doyen of molecular biology, to the same allegation: 'If scientists don't play God, who else is going to?' [1]. For the ETC Group, such declarations simply expose the incurable hubris from which many molecular and synthetic biologists suffer [52].

It seems that synthetic biologists can switch rather easily from a posture of defiance or arrogance to a posture of humility and back again. Commenting on debates on nanotechnology, the French philosopher Jean-Pierre Dupuy notes that scientists often oscillate between 'two opposed attitudes: on the one hand, vainglory, an excessive and often indecent pride; and on the other, when it becomes necessary to silence critics, a false humility that consists of denying that one has done anything that departs from the usual business of normal science' [24]. As a philosopher, Dupuy says he is less disturbed by 'a science that claims to be the equal of God' than by a 'false humility' that actually denies the essential distinction between life and non-life (ibid.). It seems to me that it might be helpful to consider the two contrasting postures, arrogance and humility, as different registers from the same rhetorical repertoire, which scientists can play according to the demands of the situation. ${ }^{6}$ If the situation demands that critics be silenced, scientists will indeed play the register of humility.

When, in a recent interview, Drew Endy was asked if the creation of new life forms should not be left to God, he played the register of humility with aplomb:

'I don't view [my research] projects as creating life, but rather [as] construction projects. For me as an engineer, there is a big difference between the words creation and construction. Creation implies I have unlimited power, perfect understanding of the universe, and the ability to manipulate matter at a godlike level. That's not what I have. I have an imperfect understanding, a budget, limited resources, and I can only manipulate things quite crudely. In that context, with those constraints, I'm a more humble constructor.' [49]

\footnotetext{
${ }^{6}$ Georgiana Kirkham notes that the defence of alchemy during the Middle Ages and the Renaissance already oscillated between a 'more modest view', which saw the alchemist's work as merely imitating nature, and a 'more optimistic view', which it as allowing human beings to surpass nature. She recognizes the same ambivalence in justifications of modern biotechnology: 'While it seems inconsistent to put forward both these conceptions at the same time, they remain as conflated now as they were in the Middle Ages and early modern period' ([38]: 77).
} 


\section{A Theological Excursion}

Given the seemingly religious character of the 'playing God' argument, we might expect theologians to be able to enlighten us about its precise status from a doctrinal point of view. In this regard Ted Peters, Professor of Systematic Theology at Berkeley, California, has a surprise for us in store. He claims that 'playing God' is by no means a theological term; on the contrary, it articulates a secular rather than a religious vision ([46]: 2 and 13; [47]). He also sees no principled objections of a religious nature against making new life forms: 'What Venter is doing is an extremely complicated form of animal breeding. We're going to be changing the face of the planet no matter what. The question is do we want to do it responsibly or not?' [8]. The Ethics of Genomics Group, the panel of bioethicists and theologians installed by Venter, also rejected quasireligious objections against far-reaching human interference with life processes: 'Too often, concern about "playing God" has become a way of forestalling rather than fostering discussion about morally responsible manipulation of life.' ([15], 2088).

Obviously, such responses come from more latitudinarian schools of thought. One notion that cannot be simply rejected out of hand is that the members of Venter's ethical panel may have been chosen partly because of their liberal views. Needless to say, there are also more orthodox views in religious circles. A liberal theologian like Ted Peters would not pretend to speak on behalf of all believers. In this connection the expositions of the Dutch theologian Frits de Lange on the doctrinal differences between orthodox and heterodox views are particularly illuminating, even though he confines his discussion to the various denominations within Protestantism. De Lange distinguishes between the restoration model of redemption, which is endorsed by orthodox Protestants and which considers redemption as a return to the situation before the Fall, and the liberal model of redemption, which sees redemption as the completion or perfection of Creation. The latter model is characterized as follows:

'Creation is not a separate act of God in the beginning, but an ongoing, dynamic process in history (creatio continua). Sinfulness in this connection is just the blockage that occurs when salvation is frustrated by people. Ethics here is forward-looking. The good creation can be better; it is still before us. It is the future that supplies the norm, not the past.' [20].

In this view the relationship between creator and creature is such that man can be promoted to the position of creator next to God; he is, in the words of the Lutheran theologian Philip Hefner, 'created cocreator' [32]. ${ }^{7}$ De Lange points out that such religious beliefs lead to a largely unrestrained optimism with regard to the possibilities of genetic technologies: '[Ted] Peters often goes so far as to suggest that almost anything that can be done technologically is also morally acceptable, as long as it is "good" for people' [20]. Orthodox Protestants would rather be guided by the idea that man is inclined to all evil and incapable of doing any good. De Lange summarizes the two positions as follows:

'Whoever considers Creation as creatio continua and man in this connection as created co-creator [...] will subscribe to liberal and progressive bioethics. Whoever emphasizes the weight of sinfulness and accentuates the discontinuity between human history and God's culmination, on the other hand, will defend a more restrictive ethics and rather point to the risks and hazards involved in tampering with hereditary structures.' (ibid.).

It is sometimes difficult to distinguish the "progressive' views of liberal theologians from the metaphysical ruminations of synthetic biologists. MIT Professor George Church, for one, provides a slightly secularized version of the theological doctrine that man can act as a created co-creator:

'We seem to be "designed" by nature to be good designers. In that sense we're part of some huge recursive design, but we're not doing something we're not designed (and microevolved) to do. Engineering is one of the main things that humans do well. [...] It's just what we do and it's natural.' [10]

\footnotetext{
${ }^{7}$ Similar notions can also be found in (liberal) Judaism: 'As Jewish ethicist Elliot Dorff points out, people are God's partners in the ongoing act of creation when we improve our lot in life' [19]. Here too this view leads to 'optimism in the face of scientific uncertainty about unanticipated consequences' (ibid.).
} 
In other words, Nature has designed man to be a designer, just as in the eyes of the liberal theologians, the Creator has created man to be a co-creator. In both cases, man's creations, including synthetic life forms, will be considered natural and acceptable.

\section{What is Life? A Silly Question?}

Venter's bioethical panel also busied itself with the challenges that synthetic biology raises with regard to received cultural views on life. In an article published in Science magazine in December 1999, the panel stated that the attempt to create a minimal genome (and by implication the rise of synthetic biology) can be interpreted as the culmination of a long-standing reductionist research agenda about the meaning and origin of life. This (interim) last step, more than any previous steps, would place the question 'What is life?' at the centre of the debate. As might be expected, the panel of liberally-minded bioethicists and theologians did not object to the attempt to create a minimal genome as such. What they warned against, however, was the 'wrong conclusions' that researchers, the general public or the press could draw from such an attempt:

'There is a serious danger that the identification and synthesis of minimal genomes will be presented by scientists, depicted in the press [reference omitted], or perceived by the public as proving that life is reducible to or nothing more than DNA. But life need not be understood solely in terms of what technology permits scientists to discover. This may threaten the view that life is special.' ([15]: 2088; my italics).

The bioethicists and theologians seem to be dispensing far too easily with the issue here. In the near future we may be confronted with situations in which various new life forms will be routinely assembled by synthetic biologists as they see fit; while, according to the panel, we should keep saying to ourselves that these biological syntheses do not have any real cultural significance and that life remains 'special' and is certainly not reducible to 'mere' DNA. As if the only thing we need to guard against is that things are presented this way. A very sanctimonious thought indeed!
Meanwhile, Arthur Caplan, a prominent member of Venter's panel, has distanced himself somewhat from the panel's appeasing statement. 'While creating new life may not be playing God', says Caplan, 'it has revolutionary implications for how we see ourselves. When we can synthesize life, it makes the notion of a living being less special.' [14]. Now that our view of life and our self-image are directly affected by the new technological potential to make artificial life forms, it seems that the question is no longer seen as just a matter of drawing the 'wrong' conclusions from such developments or of the way things are presented.

The scientific journal Nature entered the debate on the meaning of life with an editorial published on 28 June 2007 under the heading "Meanings of "life" [43]. As usual, the editorial was unsigned, but in this particular case we know that the publicist Philip Ball is responsible for its content, because an earlier version is posted on his personal blogspot under the title 'What is Life? A silly question' [4]. Ball's comment was triggered by the response of the ETC Group to Venter's recent scientific feats, in particular Pat Mooney's previously quoted statement: 'For the first time, God has competition.' The editorial in Nature argues that synthetic biology would do us an immense service if it were to free us once and for all from the view_-branded as 'vitalism' - that a qualitative difference exists between inert and living matter. Precisely because such a difference does not exist, the editorial argues, the concomitant notion of 'creating life', to which the western cultural tradition, from the myths of the golem and the homunculus to the Frankenstein story attaches such great importance, is 'close to meaningless' ([43]: 1032). Even scientists trying to set up criteria for what constitutes life are accused of exhibiting a vitalist deviation. We have to rid ourselves of the idea, the editorial insists, that life is 'a precise scientific concept'. Instead, the 'contextual contingency' and the 'ambiguity' of the term 'life' are highlighted. Neither is life a solitary phenomenon, the editorial further explains, because cells come together in colonies and organisms in ecosystems. The editorial finally rejects the religious dogma according to which a 'divine spark' would turn a fertilized egg into an inherently valuable embryo. The formation of a new being is gradual, contingent and precarious. There are no thresholds or qualitative transitions, let alone moral thresholds: 'Synthetic biology's view of life as a molecular 
process lacking moral thresholds at the level of the cell is a powerful one' ([43]: 1032).

The intervention of Nature in the debate on the meaning of life is remarkable for several reasons. Ironically, the editorial draws precisely the conclusion that, according to Venter's ethical panel, should not be drawn from the new scientific and technological developments, viz., that life is not 'special'. However, the editorial also employs post-modern qualifications such as 'ambiguous', 'contingent' and 'contextual', which suggest a positive characterization of the meaning of 'life' after all (just as the remark that life is not a solitary affair can be read with a positive twist). Furthermore, the question needs to be asked whether the rejection of thresholds and qualitative transitions is warranted on purely natural scientific grounds or whether it stems from a preconceived dogma that only gradual transitions exist. ${ }^{8}$ One might wonder if Nature's editorial board would be willing to reject the rather unique and fairly liberal British legislation that regulates embryonic stem cell research on the same grounds. The UK legislation allows stem cell research on embryos (or rather 'pre-embryos') until the age of 14 days. Proponents justify this age limit by pointing out that this is the moment when the so-called primitive streak appears and cells start to differentiate ([34]: 115). One could say that in this case an ethical commission (the Warnock Commission) has given a moral meaning to a 'natural' biological transition or marking point. Consistency would demand that Nature reject this liberal solution.

\section{Conclusion}

In the concluding pages of Frankenstein's Footsteps, Jon Turney notes that the story of Frankenstein has

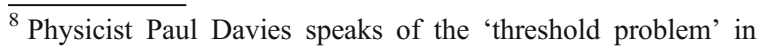
connection with the quest to explain the origin of life: 'Only when organic molecules achieve a certain very high level of complexity can they be considered as "living", in the sense that they encode a huge amount of information in a stable form and not only display the capability of storing the blueprint for replication but also the means to implement that replication. The problem is to understand how this threshold could have been crossed by ordinary physical and chemical processes without the help of some supernatural agency' ([17]: 68). It is thus possible to recognize the existence of a threshold between inert matter and life without appealing to a life-force or a divine spark!
}

outlived its former usefulness and nowadays tends to foster a sterile polarization of the debate on new advances in the life sciences. The same could perhaps be said of the standard objection of 'playing God', which, according to some, has been reduced to a facile journalistic cliché or an alarmist slogan. However, it would not be acceptable in a liberal democracy to ban allusions to the Frankenstein theme or the 'playing God' argument in public debates. If participants think that these kinds of arguments help to convey their concerns or promote their cause, they cannot be prevented from using them.

Still, it may come across as a little weird for secular organizations like the ETC Group to accuse synthetic biologists of assuming the role of God (and only slightly less weird to compare them with Dr Frankenstein). Indeed, as the Christian philosopher Gordon Graham notes, '... if, as the secular world believes, there is no God, how could there be any danger of human beings illegitimately abrogating to themselves His function?' ([31]: 145). ${ }^{9}$ The Dutch physicist-cum-theologian Willem B. Drees also notes that even non-believers often find 'playing God' a useful metaphor in criticizing new technologies ([23]: 651). A possible answer to the paradox of 'playing God without God' may lie in Ted Peters' hint that the God of 'playing God' is not necessarily the God of the Bible, but rather 'deified nature' ([47]: 383). It is the presumed sacredness of nature that the modern life sciences threaten to profane. Also to modern secular minds, there appear to be lines that may not be crossed and boundaries that may not be breached (the phrase used by Pat Mooney in his comment on Venter's patent), even in the absence of a god or gods who have the authority to institute such lines and boundaries in the first place. Overstepping these boundaries may be construed as inviting unknown and unprecedented risks. To accuse scientists of playing God may thus be just another way of alerting the wider public to the recklessness of their pursuits in the

\footnotetext{
${ }^{9}$ In a discussion with the militant atheist Richard Dawkins, the author of The God Delusion, Craig Venter also argued: 'Where there is no God, one also cannot play God' (Venter quoted in [11]). Earlier in the discussion, Dawkins had declared: 'I suspect that the phrase "playing god" is actually a kind of, it's a bit like the boy who cried 'wolf', because accusing a scientist of playing god is obviously stupid. But what is not obviously stupid is accusing a scientist of endangering the future of the planet by doing something that could be irreversible.' (Dawkins quoted in [11]).
} 
relentless quest for profit and glory. As Georgiana Kirkham writes, '[i]n secular formulations, such phrases [i.e. 'playing God' and 'interfering in Nature's plan'] can act as metaphors for mistaking a considerable amount of power, knowledge and foresight for omnipotence and omniscience, and as metaphors for humans letting their power and knowledge exceed their caution' ([37]: 176). You need not be a religious believer to recognize the dangers of hubris and the wisdom of the Proverb 'Pride comes before disaster, and arrogance before a fall' (Proverbs 16:18).

There are also Christian believers who are critical of developments in the life sciences but eschew any allusion to the argument of 'playing God'. One example is the Franciscan philosopher Keith Douglass Warner O.F.M., who deliberately refrains from using this argument in his attempt to develop a Catholic ethics on agricultural biotechnology:

'Religious ethics can play a more constructive role in the debate on agricultural biotechnology by addressing [the] patent regime rather than by raising questions about "playing God" through genetically engineering germplasm, questions that are hard to answer and unlikely to be resolved in industrial societies. The Catholic social teaching tradition and its principle of the universal destination of goods fundamentally conflicts with the negative right conferred by gene patents.' ([60]: 316).

Thus Warner arrives at a very critical position with regard to biotech patents on the basis of the traditional social teaching of the Roman Catholic Church. This example is quite provocative. One could read this article as an implicit message from a Catholic priest to a secular organization like the ETC Group: stop raising questions about synthetic biologists playing God, but concentrate your critical effort on questioning the legitimacy of their patents! (By the way, in his public lectures, Venter is conspicuously silent about the role of patents in synthetic biology.)

It is by no means certain that the 'playing God' argument or references to Frankenstein will always help the groups that question the activities of life scientists. Although most scientists are quick to deny that they are attempting to play God or following in Frankenstein's footsteps, sometimes the more intrepid among them adopt a more defiant attitude. We have seen that at one point Venter invited a comparison of his team's work with that of Frankenstein by claiming 'Shelley would have loved this!'. And James Watson's famous retort 'If scientists don't play God, who else is going to?' may be another disarming counter-strike. The option of using quasi-religious arguments, for one purpose or another, is open to all parties in the debate.

So what, finally, about the question of the 'meaning' of life? The answer does not lie first and foremost in a rigorous definition. Indeed, the whole quest for a scientifically robust definition that has been triggered by the rise of synthetic biology is a red herring (cf. [5]: 26-29). What is at stake is the wider existential connotations of the question. Are we allowed to create new life at will? Or should some kind of religious awe prevent us from emulating Frankenstein? These metaphysical questions are indeed difficult to deal with. Some synthetic biologists evade the issue by denying that their constructions of artificial biological systems amount to 'creating life' at all. Venter's ethical panel superficially suggested that the new biological syntheses would not affect our cultural understanding of the 'meaning' of life. It can hardly be denied, however, that the debate on 'What is life?', which has been revitalized by the emergence of synthetic biology, is being largely conducted from a rather narrow anthropocentric perspective. In other words, the question about the meaning of life affects us mainly insofar as it concerns our own life. Thus Arthur Caplan was primarily concerned about the potentially revolutionary implications of synthetic biology 'for how we see ourselves'. The editorial in Nature on the meaning of 'life' made particular use of the advances of synthetic biology to score points against religious views on the moral sanctity of human embryos. Conversely, when the Vatican broached the subject of synthetic biology during the Good Friday meditations of 2006, the endeavour to 'modify the very grammar of life' was exclusively interpreted in the light of the 'attack on the family' allegedly perpetrated by modern secular society [61]. Whenever the subject of synthetic biology is raised in the media, the debate almost inevitably becomes focused on possible interventions in human nature and/or the consequences for human beings. The ethical debate surrounding the birth of Dolly the Sheep in 1996 is an earlier example of this narrow interest: it turned largely on the prospect of cloning humans. The same anthropocentric focus can be 
found in the following quotation from Leon Kass, a conservative bioethicist and former chair of the US President's Council on Bioethics, in which he sketches the effects of the modern life sciences:

'All of the natural boundaries are up for grabs. All of the boundaries that have defined us as human beings, boundaries between a human being and an animal on one side and between a human being and a super human being or a god on the other. The boundaries of life, the boundaries of death. These are the questions of the 21 st century, and nothing could be more important.' (Kass quoted in [54]).

The blurring of the boundary between life and death, or life and non-life, is regarded as important only insofar as it concerns one of the boundaries 'that have defined us as human beings'. Kass's statement was quoted with approval in a newspaper article by the Dutch molecular biophysicist Cees Dekker, who is also a committed Christian. Dekker writes that doommongering with regard to future science and technology is not opportune and that he is fascinated by the possibilities of synthetic biology. But the thrust of his article is directed at the 'transhumanist' quest for human enhancement [22].

Given this overwhelming dominance of anthropocentric concerns, we may hazard a prediction that as long as synthetic biology confines itself to constructing microbial biochemical factories, hardly anyone will lose any sleep over the fact that this achievement actually comes down to creating life. The same ambiguity or hidden double standard characterizes Mary Shelley's novel. It is true that Frankenstein overstepped the mark by indulging in the unhallowed arts of bestowing animation on lifeless matter, but his real transgression was that he sought to create a human being!

Open Access This article is distributed under the terms of the Creative Commons Attribution Noncommercial License which permits any noncommercial use, distribution, and reproduction in any medium, provided the original author(s) and source are credited.

\section{References}

1. Adams T (2003) The stuff of life. The observer, April 6, 2003. Retrieved September 12, 2009, from: http://www. guardian.co.uk/education/2003/apr/06/highereducation.uk1
2. Allen G (2008) Shelley's Frankenstein. Continuum, London

3. Ball P (2004) What is life? Can we make it? Prospect magazine, vol. 101, August 2004

4. Ball P (2007) 'What is life? A silly question' June 26, 2007. Retrieved September 11, 2007, from http://philipball. blogspot.com/2007_06_01_archive.html

5. Balmer A, Martin P $(\overline{2008})$ Synthetic biology: social and ethical challenges. Retrieved August 29, 2009, from University of Nottingham, Institute for Science and Society Website: http://nottingham.academia.edu/AndrewBalmer/ Papers/51276/Synthethic-Biology-Social-and-EthicalChallenges

6. Benner S (2008) Biology from the bottom up. Nature 452:692-694

7. Bensaude-Vincent B (2009) Philosophy of chemistry. In: Brenner A, Gayon J (eds) French studies in the philosophy of science. Springer, Berlin, pp 165-186

8. Borenstein S (2007) 'Scientists struggle to define life', USA Today, August 19, 2007. Retrieved September 12, 2009, from: http://www.usatoday.com/tech/science/2007-8-19life_N.htm

9. Brenner S (2001) My Life in science. Biomed Central, London

10. Brockman J (2006) Constructive biology: George Church. Edge: The third culture, June 26 2006. Retrieved from http://www.edge.org/3rd_culture/church06/church06 index.html

11. Brockman J (2008) Life: A gene-centric view. Craig Venter \& Richard Dawkins. A conversation in Munich. Edge: the third culture. Retrieved September 4, 2009, from http:// www.edge.org/documents/dawkins_venter_index.html

12. Campos L (2009) That was the synthetic biology that was. In: Schmidt M, Kelle A, Ganguli-Mitra A, de Vriend H (eds) Synthetic biology: the technoscience and its societal consequences. Springer, Berlin, pp 5-21

13. Carey J (1999) Playing God in the lab: gene pioneers are on the threshold of creating life. Business Week, April 26, 1999. Retrieved September 12, 2009, from: http://www. businessweek.com/archives/1999/b3626158.arc.htm

14. Carey J (2007) On the brink of artificial life. Business Week, June 25, 2007. Retrieved September 12, 2009, from: http://www.businessweek.com/magazine/content/07_26/ b4040047.htm

15. Cho MK, Magnus D, Caplan AL, McGee D, the Ethics of Genomics Group (1999) Ethical considerations in synthesizing a minimal genome. Science 286:2087-2090

16. Darwin E (2006 [1803]) The temple of nature: or, the origin of society, edited by Martin Priestman. Retrieved September 10, 2009, from www.rc.umd.edu/editions/ darwin_temple/toc.html

17. Davies P (1990) God \& the new physics. Penguin Books, London

18. Davies K (2002) Cracking the genome: inside the race to unlock human DNA. The Free, New York

19. Davis D (2003) A tale of two creatures: Jewish and Christian attitudes towards cloning, The Park Ridge Center for Health, Faith and Ethics. Retrieved September 12, 2009, from: http:/www.parkridgecenter.org/Page60.html

20. de Lange F (1998) Voor God spelen? Religie, ethiek en gentechnologie [Playing God? Religion, Ethics and Gene Technology]. Tijdschrift voor Theologie 4:394-410 
21. de Vriend H (2006) Constructing life: early social reflections on the emerging field of synthetic biology. (The Hague: Rathenau Institute). Retrieved September 12, 2009, from Rathenau Institute Web site: http//www.rathenauinstituut. com/files/WED97\%20Constructing\%20Life\%202006.pdf

22. Dekker C (2007) Stel grenzen aan het gesleutel aan de mens [Put limits on tampering with human beings]. NRC Handelsblad, November 10, 2007

23. Drees WB (2002) "Playing God? Yes!" Religion in the light of technology. Zygon 37:643-654

24. Dupuy J-P (2008) Cybernetics is an antihumanism: advanced technologies and the rebellion against the human condition. The global spiral. Retrieved September 12, 2009 from http://www.metanexus.net/magazine/tabid/68/id/ 10544/Default.aspx

25. Dutch Parliament (2004) Kamerstukken I 2003/04, 26568 (R1638), B

26. Endy D (2005) Foundations for engineering biology. Nature 238:449-453

27. ETC Group (2007) Goodbye, Dolly ... Hello, Synthia! J. Craig Venter Institute Seeks Monopoly Patents on the World's First-Ever Human-Made Life Form. Retrieved September 12, 2009, from: http://www.etcgroup.org/en/ materials/publications.html?pub id $=631$

28. Forster AC, Church GM (2007) Synthetic biology projects in vitro. Genome Res 17:1-6

29. Goodfield J (1977) Playing God: genetic engineering and the manipulation of life. Hutchinson \& Co., London

30. Gould SJ (1996) The monster's human nature. In: Gould SJ (ed) Dinosaur in a haystack. Cape, London, pp 53-62

31. Graham G (2002) Genes: a philosophical inquiry. Routledge, London

32. Hefner P (1993) The human factor: evolution, culture and religion. Augsburg Fortress, Minneapolis

33. J. Craig Venter Institute (2007) Minimal bacterial genome. US Patent Application 20070122826, 31 May 2007 (filed 12 Oct 2006)

34. Jasanoff S (2005) Designs on nature: science and democracy in Europe and the United States. Princeton University Press, Princeton

35. Kant I (1996) Critique of pure reason. Translated by W.S. Pluhar. Hackett, Indianapolis 1787

36. Kearnes M (2008) Informationalising matter: systems understanding of the nanoscale. Spontaneous Generations 2:99-111

37. Kirkham G (2006) 'Playing God' and 'vexing nature': a cultural perspective. Environ Values 15:173-195

38. Kirkham G (2009) Is biotechnology the new alchemy? Stud Hist Philos Sci 40:70-80

39. Lederer S (2002) Frankenstein: penetrating the secrets of nature. Rutgers University Press, New Brunswick

40. Maienschein J (2009) Controlling life: from Jacques Loeb to regenerative medicine. J Hist Biol 42:215-230

41. McEuen P, Dekker C (2008) Synthesizing the future. ACS Chemical Biology 3:10-12

42. Mooney C (2002) Nothing wrong with a little Frankenstein. Washington Post, December 1, 2002. Retrieved September 12, 2009, from: http://www.msu.edu/ pennock5/courses/ ALife/Wash\%20Post \%20Dec\%20202002b.html

43. Nature (2007) Editorial: meanings of 'life': synthetic biology provides a welcome antidote to chronic vitalism. Nature 447:1031-1032
44. O’Malley MA, Powel A, Davies JF, Calvert J (2008) Knowledge-making distinctions in synthetic biology. BioEssays 30:57-65

45. Pauly PJ (1987) Controlling life. Jacques Loeb \& The engineering ideal in biology. Oxford University Press, Oxford

46. Peters T (2002) Playing God? Genetic determinism and human freedom. Routledge, London

47. Peters T (2006) Contributions from practical theology and ethics. In: PH Clayton, Simpson ZR (eds) The Oxford handbook of religion and science. Oxford University Press, Oxford, pp 372-387

48. Pollan M (1998) Playing God in the garden. New York Times, 25 October 1998. Retrieved September 12, 2009, from: http://www.michaelpollan.com/article.php?id=73

49. Reed A (2009) Designing life: a look at synthetic biology. Retrieved September 12, 2009, from http://scienceinsociety. northwestern.edu/content/articles/2008/medill-reports/jan/ endy/designing-life-a-look-at-synthetic-biology

50. Regalado A (2005) Biologist Venter aims to create life from scratch. Wall Street Journal, June 29, 2005. Retrieved September 12, 2009, from http://www.post-gazette.com/pg/ 05180/530330.stm

51. Rollin BE (1995) The Frankenstein syndrome: ethical and social issues in the genetic engineering of animals. Cambridge University Press, Cambridge

52. Shand H, Thomas J, Wetter KJ (2007) Playing God. Ecologistonline, May 1, 2007

53. Shelley M (2003) Frankenstein, or The Modern Prometheus. Penguin Books, London

54. Smith WJ (2005) Is the world ready for a superboy? - or a dogboy? Dallas Morning News, November 13, 2005. Retrieved September 12, 2009, from: http://www.discovery.org/a/3024

55. Steinz P (2002) Mrs. Frankenstein. NRC Handelsblad, June 8,2002

56. ter Gast E (2007) Biotech pioneers: a philosophical inquiry concerning the genetically engineered mouse. Dissertation, Radboud University Nijmegen

57. Torreele E (2001) From Louis Pasteur to J. Craig Venter: when biomedical scientists become bio-entrepreneurs, DND Working Group Expert Paper, Médecins Sans Frontières, October 2001

58. Turney J (1998) Frankenstein's footsteps: science, genetics, and popular culture. Yale University Press, New Haven

59. van den Belt H (2009) Philosophy of biotechnology. In: Meijers A (ed) Handbook philosophy of technology and engineering sciences. Elsevier, Burlington, pp 1149-1188

60. Warner KD (2001) Are life patents ethical? Conflict between Catholic social teaching and agricultural biotechnology's patent regime. J Agric Environ Ethics 14(3):301-319

61. White H (2006) Destruction of the family an attempt to "Modify the very Grammar of Life" says Pope's Vicar General. Retrieved September 11, 2009, from www. lifesitenews.com/ldn/2006/apr/06041306.html

62. Winner L (1977) Autonomous technology: technics-out-ofcontrol as a theme in political thought. MIT, Cambridge

63. Yeh BJ, Lim WA (2007) Synthetic biology: lessons from the history of synthetic organic chemistry. Nature Chemical Biology 3:521-525

64. Young E (2002). Venter gets go-ahead to build lifeform. New Scientist, 21 November 2002. Retrieved September 12, 2009, from: http:/www.newscientist.com/article/ dn3094-venter-gets-goahead-to-build-lifeform,html 